\section{Spinal anesthesia: a comparison of procaine and lidocaine}

Hong Hanh Le Truong MD,

Michel Girard MD MHPE FRCPC, Pierre Drolet MD FRCPC, Yvan Grenier MD FRCPC, Carl Boucher MD, Lyne Bergeron $\mathrm{MD}$
Purpose: To compare spinal procaine to spinal lidocaine with regard to their main clinical characteristics and incidence of transient radicular irritation (TRI).

Methods: In this randomized, double-blind, prospective study, patients (two groups, $n=30$ each) received either $100 \mathrm{mg}$ of lidocaine $5 \%$ in $7.5 \%$ glucose (Group L) or $100 \mathrm{mg}$ of procaine $10 \%$ diluted with I $\mathrm{ml}$ cerebrospinal fluid (Group P). After spinal anesthesia, segmental level of sensory block was assessed by pinprick. Blood pressure and the height of the block were noted each minute for the first ten minutes, then every three minutes for the next $35 \mathrm{~min}$ and finally every five minutes until regression of the block to L4. Motor blockade was evaluated using the Bromage scale. To evaluate the presence of TRI, each patient was questioned $48 \mathrm{hr}$ after surgery.

Results: Time to highest sensory level and to maximum number of segments blocked showed no difference between groups. Mean time for sensory regression to $\mathrm{T} I 0$ and for regression of the motor block were shorter in Group P. Eighty minutes following injection, sensory levels were lower in Group P. Five patients had inadequate surgical anesthesia in Group $P$ and only one in Group L. No patient in Group P had TRI (95\% Cl 0-12\%) while eight (27\%) in Group $\mathrm{L}$ did (95\% Cl 12-46\%).

Conclusions: Procaine 10\% was associated with a clinical failure rate of $14.2 \%$. This characteristic must be balanced against an absence of TRI, which occurs more frequently with the use of lidocaine $5 \%$

Objectif : Comparer la procaine et la lidocaïne quant à leurs caractéristiques cliniques et à l'incidence de "transient radicular irritation" (TRI).

Méthodes : Dans cette étude randomisée, prospective et à doubleinsu, les patients recevaient $100 \mathrm{mg}$ de lidocaine $5 \%$ dans du glucose $7,5 \%$ (Groupe L) ou $100 \mathrm{mg}$ de procaine $10 \%$ diluée avec $1 \mathrm{ml}$ de liquide céphalo-rachidien (Groupe P). Le niveau sensitif a été évalué à l'aide d'une aiguille. La pression artérielle et le niveau du bloc ont été notés chaque minute pour dix minutes, puis chaque trois minutes pour les 35 min suivantes et puis chaque cinq minutes jusqu'au niveau $L 4$.
Le bloc moteur a été évalué à l'aide de l'échelle de Bromage. Chaque patient a été questionné $48 \mathrm{hr}$ après l'intervention pour évaluer la présence de TRI

Résultats : Le temps pour atteindre le niveau sensitif maximum et le nombre maximum de segments bloqués étaient comparables. Le temps moyen pour la récupération sensitive à TlO et le temps de récupération du bloc moteur ont été plus courts dans le Groupe $P$. Quatre-vingts minutes après l'injection, le niveau sensitif était plus bas dans le Groupe $P$. Cinq patients du Groupe $P$ ont eu une anesthésie inadéquate et un seul dans le Groupe $L$. Aucun patient du Groupe $P$ n'a manifesté de TRI (IC $95 \% 0-12 \%$ ) alors qu'il y en a eu huit (27 \%) dans le Groupe L (IC $95 \%$ 12-46\%).

Conclusions : La procaine pourrait être une solution de remplacement a la lidocaïne. II y a moins de TRI lorsque la procaine est utilisée. On doit évaluer plus à fond les stratégies pour diminuer le taux d'échec avec la procaïne.

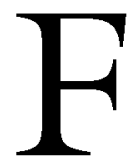

O R the last $50 \mathrm{yr}$, lidocaine has been the local anesthetic of choice for short procedures under spinal anesthesia. Recently, it has been associated with transient radicular irritation (TRI) ${ }^{1,2}$ which makes its use less and less acceptable. ${ }^{3}$ Therefore, alternatives to lidocaine are needed. Procaine, which also has a short duration of action, ${ }^{4}$ could be an alternative to lidocaine.

This randomized, double-blind, prospective study compares the clinical characteristics of procaine to those of lidocaine during spinal anesthesia and the incidence of TRI associated with both medications.

\section{Methods}

After approval of the study by our institutional Ethics Committee, patients gave informed, written consent. We studied 66 patients, ASA I and II, scheduled for surgery $(<60 \mathrm{~min})$ under spinal anesthesia. Patients were excluded if they were allergic to local anesthetics

From the Département d'anesthésie-réanimation, Hôpital Maisonneuve-Rosemont and Université de Montréal, Montréal, Québec, Canada.

Address correspondence to: Dr. Michel Girard, Département d'anesthésie-réanimation, Hôpital Maisonneuve- Rosemont, 5415 boul. L'Assomption, Montréal, Québec, HlT 2M4, Canada. Phone: 514-252-3426; Fax: 514-252-3542; E-mail: girardmi@videotron.ca Presented at the June 1999 Canadian Anesthesiologists' Society meeting by Dr. Le Truong at the resident's competition.

Accepted for publication January 16, 2001. 
or p-aminobenzoic acid (PABA) or complained of back pain. Patients were randomized to receive 100 $\mathrm{mg}$ hyperbaric 5\% lidocaine (Group L) or $100 \mathrm{mg}$ of procaine $10 \%$ diluted with $1 \mathrm{ml} \mathrm{CSF} \mathrm{(Group} \mathrm{P).} \mathrm{If}$ needed, patients received midazolam $1 \mathrm{mg}$ iv before anesthesia. Prior to spinal anesthesia, patients received a bolus of Lactated Ringer's solution $10 \mathrm{ml} \cdot \mathrm{kg}^{-1}$. After routine installation of monitors (Datex AS/3), a baseline blood pressure was taken. Dural puncture was performed in the sitting position, midline at L3-4, with a 27-gauge Whitacre needle. The anesthetic was injected within ten seconds with the bevel of the needle oriented in a cephalic direction and the end of the injection was used as T0. In the supine position, the segmental level of sensory block was assessed by pinprick on the left side. A blinded observer noted blood pressure and the height of the block each minute for the first ten minutes, then every three minutes for the next $35 \mathrm{~min}$ and, finally, every five minutes until regression to L4. Ephedrine $(5-10 \mathrm{mg})$ was administered if the systolic pressure fell by more than $20 \%$ of the baseline value or below $90 \mathrm{mmHg}$. Motor blockade was assessed (Bromage scale) upon arrival in the recovery room and every five minutes thereafter. Failure of spinal anesthesia was defined as a sensory level insufficient to perform surgery or a surgery that outlasted duration of sensory blockade. Meperidine $(5-15 \mathrm{mg}$ ) was used if analgesia was insufficient and metoclopramide $(10 \mathrm{mg})$ was given for nausea.

TRI was defined as pain in the legs or back, of moderate or severe intensity (pain score $>3 / 10$ ), ${ }^{5}$ appearing after resolution of anesthesia and lasting more than $24 \mathrm{hr}$. To evaluate the presence of TRI, a blinded observer contacted the patients $48 \mathrm{hr}$ after surgery. A comprehensive symptom checklist was used. Patients reporting symptoms rated the degree of discomfort using a 10 -point verbal scale $(0=$ no pain to $10=$ worst conceivable pain). Analgesic intake was recorded. Care was taken to differentiate TRI from other sources of pain.

The results are expressed as mean \pm standard deviation. A $P<0.05$ was considered significant. To compare demographic data, maximum number of blocked segments, time to reach the highest segment, delay for regression to T10 and maximum decrease of the blood pressure, T test for unpaired value, Fisher's exact test, chi-square test or Mann-Whitney U test were used when appropriate. Multiple comparisons between groups were made with either repeated-measures ANOVA (blood pressure) or Mann-Whitney U test with Bonferroni's correction (number of blocked segments). Sensory and motor block regression were analysed with Kaplan-Meier curves and compared with a log-rank.
Considering a difference of $20 \mathrm{~min}$ for the regression of sensory blockade to T10 between groups to be clinically relevant, this study exhibits a power of $80 \%$ and an alpha error of 0.05 .

Results

There was no difference between groups for demographics, duration and type of surgery or patient positioning (Table I). Time to highest sensory level and maximum number of segments blocked were not different. Mean times for sensory regression to T10 and regression of motor blockade were shorter in Group P (Table II). Residual motor block was greater in Group L (Figure 1). After $80 \mathrm{~min}$, sensory levels were lower in Group P (Figure 2).

Doses of midazolam (Table I) are similar. The doses of ephedrine administered and systolic blood pressures for each interval showed no difference. The use of metoclopramide was equivalent in each group (Group P: $n=3$, Group L: $n=1$ ). Two patients in each group received meperidine $i v$ in the postanesthesia care unit. Intake of oral medication, at home, was not different.

Five patients had inadequate surgical anesthesia in Group P (four due to insufficient sensory level, one

TABLE I Demographic data, midazolam dose and type of surgery

\begin{tabular}{lll}
\hline & $\begin{array}{l}\text { Group } P \\
(n=30)\end{array}$ & $\begin{array}{l}\text { Group } L \\
(n=30)\end{array}$ \\
\hline Age $(\mathrm{yr})$ & $38 \pm 9$ & $41 \pm 11$ \\
Weight $(\mathrm{kg})$ & $69 \pm 12$ & $74 \pm 10$ \\
Height $(\mathrm{cm})$ & $168 \pm 8$ & $172 \pm 7$ \\
Sex $(\mathrm{M} / \mathrm{F})$ & $20 / 10$ & $24 / 6$ \\
Midlazolam (mg) & $1.4 \pm 0.17$ & $1.0 \pm 0.19$ \\
Type of surgery $(n)^{\star}$ & $15 / 15 / 0$ & $15 / 13 / 2$ \\
Position $(n) \dagger$ & $7 / 16 / 7$ & $5 / 15 / 10$ \\
\hline
\end{tabular}

Values are $n$ or mean \pm SD .

*General/gynecological/other.

†Lithotomy/supine/arthroscopy, NS.

TABLE II Characteristics of blocks

\begin{tabular}{lll}
\hline & $\begin{array}{l}\text { Group } P \\
(n=30)\end{array}$ & $\begin{array}{l}\text { Group } L \\
(n=30)\end{array}$ \\
\hline $\begin{array}{l}\text { Time from injection to highest } \\
\text { sensory level (min) }\end{array}$ & $23.0 \pm 13.9$ & $24.1 \pm 13.1$ \\
$\begin{array}{l}\text { Maximum number of blocked } \\
\text { segments above L4 ( } n)\end{array}$ & $13(7-16) \dagger$ & $13.5(9-16) \dagger$ \\
$\begin{array}{l}\text { Time for sensory regression } \\
\text { to T10 (min) }\end{array}$ & $89 \pm 26$ & $114 \pm 26^{*}$ \\
$\begin{array}{l}\text { Time for regression of motor } \\
\text { block to Bromage } 4 \text { (min) }\end{array}$ & $89 \pm 22$ & $115 \pm 24^{*}$ \\
\hline
\end{tabular}

Values are mean $\pm \mathrm{SD}$, except $\dagger$ median (range), ${ }^{\star} P<0.0005$. 


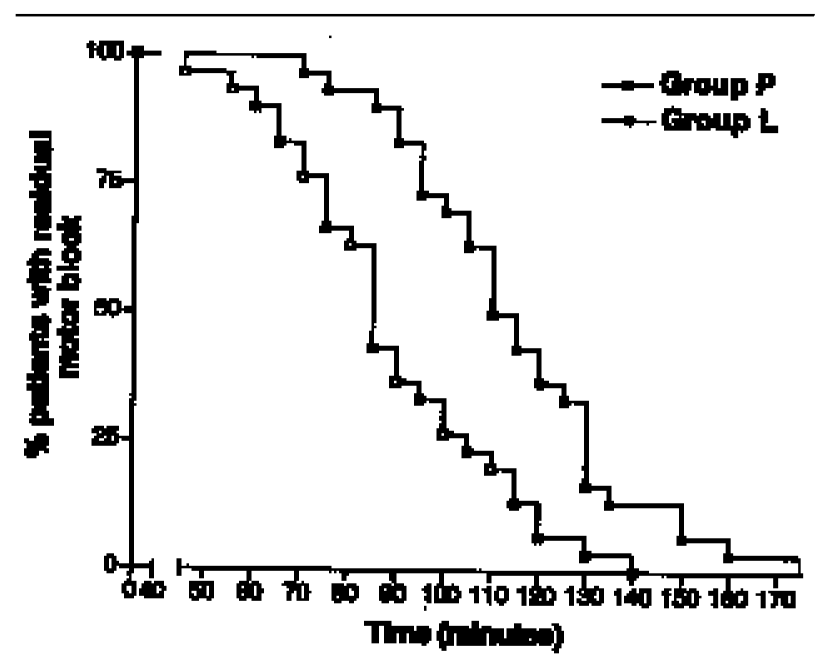

FIGURE 1 Recovery from motor block, Kaplan-Meier curves, log-

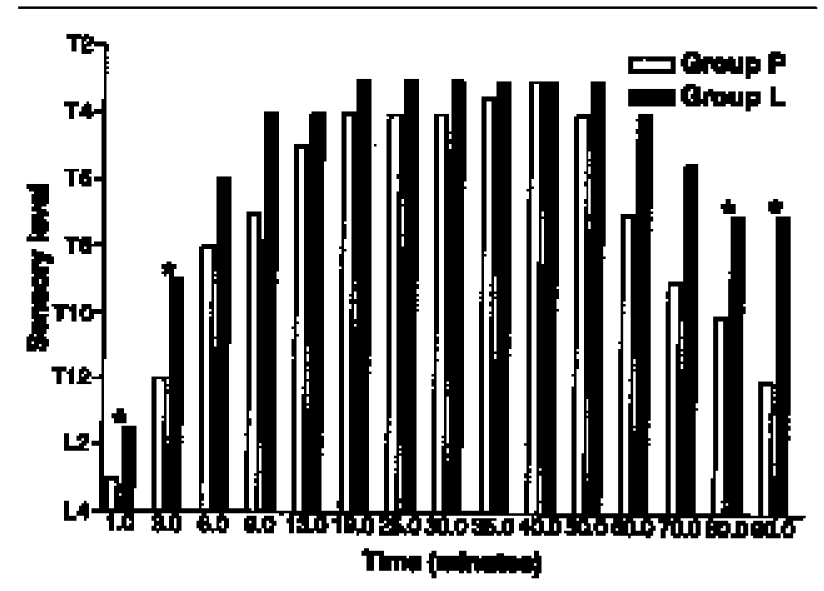
rank test, $P<0.0005$.

previous experience, ${ }^{4}$ might dismiss its use, unless additives can improve this.

A dose of $100 \mathrm{mg}$ of each local anesthetic was chosen. This dose is considered the maximum safe dose for procaine, while lidocaine $100 \mathrm{mg}$ has been widely investigated and used clinically. For lidocaine, neither the reduction of the dose, ${ }^{5}$ nor of its concentration, ${ }^{7,8}$ appears to modify the incidence of TRI. It could be argued that the doses used are not equipotent, the lidocaine/procaine potency ratio being described classically as $2 / 1$. However, little data exist to document this ratio. ${ }^{9}$

The only study ${ }^{6}$ comparing the incidence of TRI between procaine and lidocaine showed results similar (lidocaine: $31 \%$, procaine: $6 \%$ ) to ours. The same dose of procaine $(100 \mathrm{mg})$ was used, while that of lidocaine was $50 \mathrm{mg}$ to respect the alleged potency ratio mentioned earlier. The failure rate with procaine (17\%) was similar to ours (14\%). Similarly, patients receiving procaine had a greater tendency to be nauseated (17\%) than those receiving lidocaine $(3 \%)$ as in our work (procaine: $10 \%$, lidocaine: $3.3 \%$ ).

In this study, the incidence of TRI with lidocaine $(27 \%)$ is consistent with the literature where the incidence ranges up to 30 to $40 \%{ }^{8}$

Conclusion

When administered in the same mg dosage, the effective duration of spinal anesthesia with procaine $10 \%$ is shorter than that obtained with lidocaine $5 \%$. Procaine $10 \%$ does not provide a sensory or motor blockade equivalent to lidocaine $5 \%$. Finally, procaine is associated with a higher failure rate, but the incidence of TRI is lower than with lidocaine.

Acknowledgment

FIGURE 2 Sensory level as a function of time, Mann-Whitney U test The authors wish to thank Mrs. Christiane Côté B.Sc. for each interval with Bonferroni correction for multiple comparisons, for her assistance in the data collecting for this work. median, ${ }^{*} P<0.05$.

due to insufficient duration of block) and one in Group L. All required general anesthesia and were excluded from the final data analysis. No patient in Group P had TRI (95\% CI 0-12\%), while eight (27\%) in Group L did (95\% CI 12-46\%).

\section{Discussion}

Procaine could be adequate for short duration surgery. However, the high failure rate observed in the present study, although inconsistent with our own

\section{References}

1 Schneider $M$, Ettlin T, Kaufmann $M$, et al. Transient neurologic toxicity after hyperbaric subarachnoid anesthesia with 5\% lidocaine. Anesth Analg 1993; 76: 1154-7.

2 Pollock JE, Neal JM, Stephenson CA, Wiley CE.

Prospective study of the incidence of transient radicular irritation in patients undergoing spinal anesthesia. Anesthesiology 1996; 84: 1361-7.

3 de Jong $R H$. Last round for a "heavyweight"? Anesth Analg 1994; 78: 3-4.

4 Bergeron L, Girard $M$, Drolet $P$, Grenier $\Upsilon$, Le Truong $H H$, Boucher $C$ Spinal procaine with and without epinephrine and its relation to transient radicular irritation. Can J Anesth 1999; 46: 846-9. 
5 Pinczower GR, Chadwick HS, Woodland R, Lowmiller $M$. Bilateral leg pain following lidocaine spinal anaesthesia. Can J Anaesth 1995; 42: 217-20.

6 Hodgson PS, Liu SS, Batra MS, Gras TW, Pollock JE, Neal JM. Procaine compared with lidocaine for incidence of transient neurologic symptoms. Reg Anesth Pain Med 2000; 25: 218-22.

7 Pollock JE, Liu SS, Neal JM, Stephenson CA Dilution of spinal lidocaine does not alter the incidence of transient neurologic symptoms. Anesthesiology 1999; 90: 445-50.

8 Hampl KF, Schneider MC, Pargger H, Gut J, Drewe J, Drasner $K$ A similar incidence of transient neurologic symptoms after spinal anesthesia with $2 \%$ and $5 \%$ lidocaine. Anesth Analg 1996; 83: 1051-4.

9 Rowlingson JC To avoid "transient neurologic symptoms" - The search continues. Reg Anesth Pain Med $2000 ; 25: 215-7$. 